\title{
Dual Role of Hydrogen Peroxide in Arabidopsis Guard Cells in Response to Sulfur Dioxide
}

\author{
Huilan Yi, ${ }^{1}$ Xin Liu, ${ }^{1,2}$ Min Yi, ${ }^{1,3}$ and Gang Chen ${ }^{2}$ \\ ${ }^{1}$ School of Life Science, Shanxi University, Taiyuan 030006, China \\ ${ }^{2}$ Shanxi Provincial Guoxin Energy Development Group Co., LTD., Taiyuan 030006, China \\ ${ }^{3}$ Department of Statistics, University of Missouri-Columbia, Columbia, MO 65211, USA
}

Correspondence should be addressed to Huilan Yi; yihl@sxu.edu.cn

Received 28 April 2014; Accepted 8 September 2014; Published 30 September 2014

Academic Editor: Mugimane Manjanatha

Copyright (C) 2014 Huilan Yi et al. This is an open access article distributed under the Creative Commons Attribution License, which permits unrestricted use, distribution, and reproduction in any medium, provided the original work is properly cited.

\begin{abstract}
Sulfur dioxide $\left(\mathrm{SO}_{2}\right)$ is a major air pollutant and has significant impacts on plant physiology. Plant can adapt to $\mathrm{SO}_{2}$ stress by controlling stomatal movement, gene expression, and metabolic changes. Here we show clear evidences that $\mathrm{SO}_{2}$-triggered hydrogen peroxide $\left(\mathrm{H}_{2} \mathrm{O}_{2}\right)$ production mediated stomatal closure and cell death in Arabidopsis leaves. High levels of $\mathrm{SO}_{2}$ caused irreversible stomatal closure and decline in guard cell viability, but low levels of $\mathrm{SO}_{2}$ caused reversible stomatal closure. Exogenous antioxidants ascorbic acid (AsA) and catalase (CAT) or $\mathrm{Ca}^{2+}$ antagonists EGTA and $\mathrm{LaCl}_{3}$ blocked $\mathrm{SO}_{2}$-induced stomatal closure and decline in viability. AsA and CAT also blocked $\mathrm{SO}_{2}$-induced $\mathrm{H}_{2} \mathrm{O}_{2}$ and $\left[\mathrm{Ca}^{2+}\right]_{\text {cyt }}$ elevation. However, EGTA and $\mathrm{LaCl}_{3}$ inhibited $\mathrm{SO}_{2}$-induced $\left[\mathrm{Ca}^{2+}\right]_{\text {cyt }}$ increase but did not suppress $\mathrm{SO}_{2}$-induced $\mathrm{H}_{2} \mathrm{O}_{2}$ elevation. These results indicate that $\mathrm{H}_{2} \mathrm{O}_{2}$ elevation triggered stomatal closure and cell death via $\left[\mathrm{Ca}^{2+}\right]_{\text {cyt }}$ signaling in $\mathrm{SO}_{2}$-stimulated Arabidopsis guard cells. NADPH oxidase inhibitor DPI blocked $\mathrm{SO}_{2}$-induced cell death but not the stomatal closure triggered by low levels of $\mathrm{SO}_{2}$, indicating that NADPH oxidasedependent $\mathrm{H}_{2} \mathrm{O}_{2}$ production plays critical role in $\mathrm{SO}_{2}$ toxicity but is not necessary for $\mathrm{SO}_{2}$-induced stomatal closure. Our results suggest that $\mathrm{H}_{2} \mathrm{O}_{2}$ production and accumulation in $\mathrm{SO}_{2}$-stimulated plants trigger plant adaptation and toxicity via reactive oxygen species mediating $\mathrm{Ca}^{2+}$ signaling.
\end{abstract}

\section{Introduction}

Sulfur dioxide $\left(\mathrm{SO}_{2}\right)$ is a harmful gas that is emitted largely from burning coal, high-sulfur oil, and fuels. During the past few decades, the concentration of $\mathrm{SO}_{2}$ in the atmosphere has increased in many areas of the world, especially in the developing countries. High levels of $\mathrm{SO}_{2}$ can injure many plant species and varieties, resulting in photosynthesis decline, growth inhibition, and even death [1-4]. Sulfur dioxide enters plants mainly through the open stomata [5]. Once it enters the leaf, $\mathrm{SO}_{2}$ is hydrated to form $\mathrm{HSO}_{3}{ }^{-}$and $\mathrm{SO}_{3}{ }^{2-}$. The toxicity of $\mathrm{SO}_{2}$ is derived from molecular species sulfite $\left(\mathrm{SO}_{3}{ }^{2-}\right)$ and bisulfite $\left(\mathrm{HSO}_{3}{ }^{-}\right)$generated after $\mathrm{SO}_{2}$ is dissolved in cellular fluid [6]. Sulfite oxidation, which is the detoxification reaction of sulfite to sulfate $\left(\mathrm{SO}_{4}{ }^{2-}\right)$, leads to the formation of reactive oxygen species (ROS) in plant cells $[7,8]$. The production and accumulation of ROS are one of the key events in plant response to $\mathrm{SO}_{2}$ [9-12].
ROS have been proposed as central components of plant response to both biotic and abiotic stresses. Under such conditions, ROS may play two very different roles: exacerbating damage or signaling the activation of defense responses [13, 14]. It has been reported that ROS act as signaling molecules mediating a variety of physiological responses, including stomatal movement and gene expression [15-17], although they can attack biomolecules such as nucleic acids, proteins, and lipids leading to cell damage and death $[16,18,19]$. Results of previous studies have shown that plants can adapt to $\mathrm{SO}_{2}$ stress by controlling stomatal movement and gene transcription $[11,12,20]$. Stomatal closure could protect the leaves against further entry of the environmental $\mathrm{SO}_{2}$, while differential gene expression could regulate the metabolic routes of plant cells providing long-term adaptation to environmental stress. However, up to now, it is not clear if the ROS production is closely associated with the initial physiological mechanisms responsible for plant responses to $\mathrm{SO}_{2}$ stress. 
ROS overproduction can trigger plant adaptation or cell damage during abiotic stress. However, there has been little overlap between these two fields of research. In the present study, guard cells of $A$. thaliana leaves, which are a welldeveloped model cell system for studying the signal transduction in plant cells [21-23], were employed to investigate the cellular mechanism of plant response to $\mathrm{SO}_{2}$ stress. To the best of our knowledge, this is the first report of $\mathrm{H}_{2} \mathrm{O}_{2}$ mediating both adaptation response (stomatal movement) and cytotoxicity (cell death) in plant response to $\mathrm{SO}_{2}$ stress. Our results show that $\mathrm{H}_{2} \mathrm{O}_{2}$ elevation triggered both stomatal closure and cell viability loss via $\mathrm{Ca}^{2+}$ signaling in $\mathrm{SO}_{2}$-treated plants.

\section{Materials and Methods}

2.1. Plant Material Preparation. Plants of Arabidopsisthaliana (L.) ecotype Columbia (Col-0) were grown in soil (Klasmann-Deilmann) in temperature-controlled growth rooms at $22^{\circ} \mathrm{C}$ with an average light intensity of $240 \mu \mathrm{moL} \mathrm{m}^{-1} \mathrm{~s}^{-1}$, a $16 \mathrm{~h}$ photoperiod per day, and $60 \%$ relative humidity.

Young fully expanded leaves were harvested from 4week-old Arabidopsis plants. The abaxial epidermes were peeled from the underside of each leaf and cut into small pieces. The isolated epidermal strips were immediately floated in $10 \mathrm{mM}$ 2-(N-morpholino)ethanesulfonic acid (MES; Bio Basic Inc.) buffer (10 mM MES-Tris, $\mathrm{pH} 7.0$, and $50 \mathrm{mM} \mathrm{KCl})$.

2.2. Determination of Stomatal Aperture. The isolated epidermal strips were incubated in $10 \mathrm{mM}$ MES buffer for $2 \mathrm{~h}$, for stomata-opening under continuous light of $180 \mu \mathrm{moL} \mathrm{m}^{-2} \mathrm{~s}^{-1}$ at $22^{\circ} \mathrm{C}$ or for stomata-closuring in the dark, and then incubated for $2 \mathrm{~h}$ in MES buffer containing a certain amount of $\mathrm{SO}_{2}$ hydrates (a mixture of sodium sulfite and sodium bisulfite, $3: 1 \mathrm{mM} / \mathrm{mM}$, prepared freshly before use) under continuous illumination of $180 \mu \mathrm{moL} \mathrm{m}^{-2} \mathrm{~s}^{-1}$ at $22^{\circ} \mathrm{C}$. Control samples were treated under the same conditions with $10 \mathrm{mM}$ MES buffer. The isolated epidermal strips were treated with a mixture of $\mathrm{SO}_{2}$ hydrates and a certain amount of antagonists which include NADPH oxidase inhibitor diphenylene iodonium (DPI, Sigma), antioxidants catalase (CAT, Sigma), and ascorbic acid (AsA, Sigma) and $\mathrm{Ca}^{2+}$ antagonists $\mathrm{LaCl}_{3}$ and ethylene glycol tetraacetic acid (EGTA, Sigma) to examine the protective effects. After $2 \mathrm{~h}$ of chemical exposure, the epidermal strips were mounted on a microscopy slide, moistened with $10 \mathrm{mM}$ MES buffer, and covered with a slip. Stomatal aperture was measured by using a digital microscope camera system (DP72, Olympus) and an attached DP2-BSW software. At least three leaves and 300 stomata per leaf were measured in each treatment and all of the experiments were independently repeated at least three times. For the recovery groups, after $2 \mathrm{~h}$ of chemical exposure, the isolated strips were resuspended in MES buffer for $2 \mathrm{~h}$ under continuous light followed by stomatal aperture measurement. For time-course experiment, the stomatal apertures were examined every five minutes after isolated strips were incubated in $\mathrm{SO}_{2}$ hydrates.
2.3. Determination of Cell Viability. Cell viability was assessed by using the method of double staining with fluorescein diacetate (FDA; Bio Basic Inc.) and propidium iodide (PI; Sigma). After $2 \mathrm{~h}$ of chemical exposure, the epidermal strips were simultaneously stained with $0.1 \mathrm{mg} \cdot \mathrm{L}^{-1} \mathrm{FDA}$ and $10 \mu \mathrm{M}$ PI for visualizing cell viability. At least three leaves and 300 guard cells per leaf were observed in each treatment and all of the experiments were independently repeated three times.

2.4. Measurement of Reactive Oxygen Species. Reactive oxygen species in guard cells of epidermal peels were detected using $2^{\prime}, 7^{\prime}$-dichlorodihydrofluorescein diacetate (DCFHDA; Beyotime) according to the methods described by Yi et al. [24]. After $2 \mathrm{~h}$ of exposure to the chemicals, the epidermal strips were incubated in $20 \mu \mathrm{M}$ DCFH-DA for $30 \mathrm{~min}$ in the dark. The mean value of fluorescence intensity, resulting from 600 guard cells in three independent experiments, represents the intracellular $\mathrm{H}_{2} \mathrm{O}_{2}$ level for each treatment.

2.5. Measurement of Intracellular $\mathrm{Ca}^{2+}$. The concentration of intracellular $\mathrm{Ca}^{2+}\left(\left[\mathrm{Ca}^{2+}\right]_{\text {cyt }}\right)$ was measured using fluo-3 acetomethoxyester (Fluo-3 AM; Beyotime) as described in our previous report [24]. The average fluorescence intensity of Fluo-3 AM obtained from three different leaves and 200 guard cells represents the $\left[\mathrm{Ca}^{2+}\right]_{\mathrm{cyt}}$ level for each treatment. All experiments were independently repeated three times.

2.6. Statistical Analysis. All values of mean and standard deviation (SD) were obtained from three independent experiments. Analysis of variance (ANOVA) and Dunnett's $t$-test were used to determine the significant differences among the control and a series of treatment groups.

\section{Results}

3.1. $\mathrm{SO}_{2}$-Evoked $\mathrm{H}_{2} \mathrm{O}_{2}$ Production Is Involved in the Regulation of Stomatal Movement. As shown in Figure $1, \mathrm{SO}_{2}$ hydrates promote stomatal closure and inhibit light-promoted stomatal opening in Arabidopsis leaves. The width of stomatal aperture decreased in a concentration-dependent manner and showed a significant decrease after the isolated strips were exposed for $2 \mathrm{~h}$ to $\mathrm{SO}_{2}$ hydrates at concentrations of 10 to $500 \mu \mathrm{M}$. However, stomatal closure evoked by low $\mathrm{SO}_{2}$ concentrations (below $200 \mu \mathrm{M}$ ) could be reversed completely after $\mathrm{SO}_{2}$ removal; otherwise the decline of stomatal aperture in high $\mathrm{SO}_{2}$ concentration $(500 \mu \mathrm{M})$ group could be partly reversed.

Time course analysis of stomatal movement showed that the diameter of the stomatal aperture decreased markedly within the first 30 minutes of exposure to $10 \mu \mathrm{M} \mathrm{SO}_{2}$ hydrates and continued to decline at a slower rate in the remaining 90 minutes of $\mathrm{SO}_{2}$ exposure (Figure $1(\mathrm{c})$ ).

$\mathrm{SO}_{2}$-induced stomatal closure was associated with an elevated $\mathrm{H}_{2} \mathrm{O}_{2}$ level in Arabidopsis guard cells. Exposure to $\mathrm{SO}_{2}$ hydrates not only caused smaller stomatal apertures 


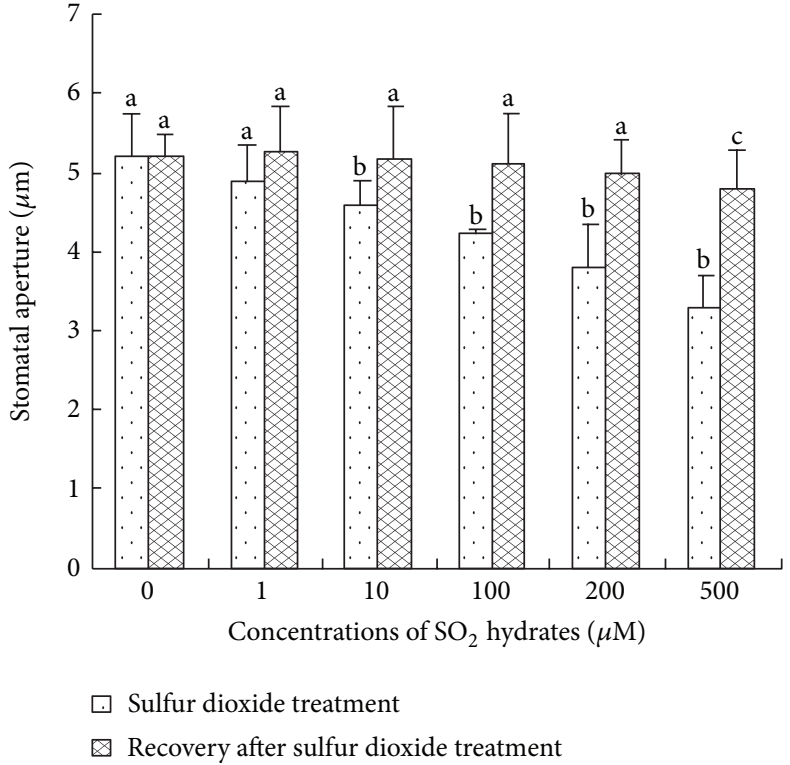

(a)

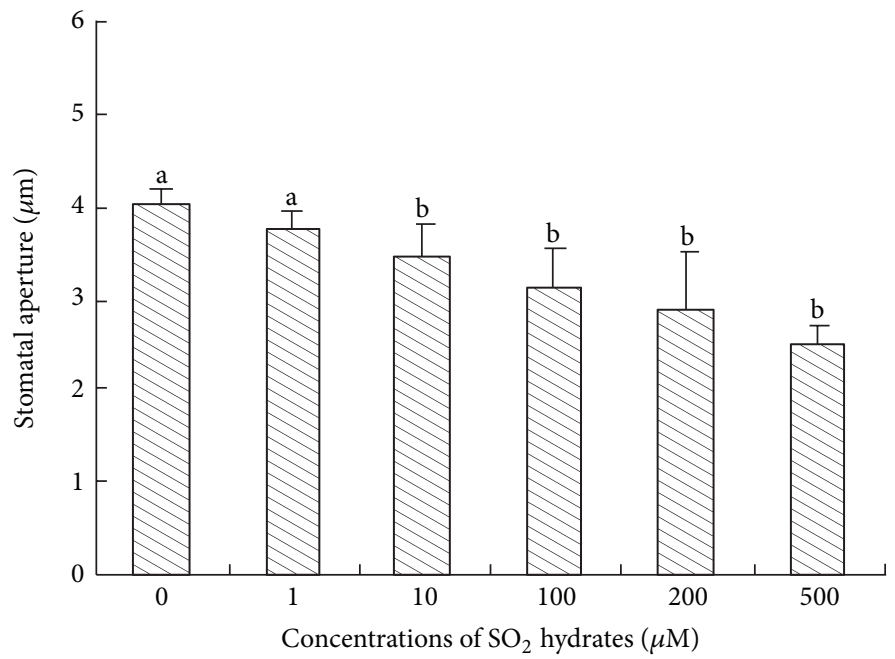

$\square$ Pretreatment in the dark

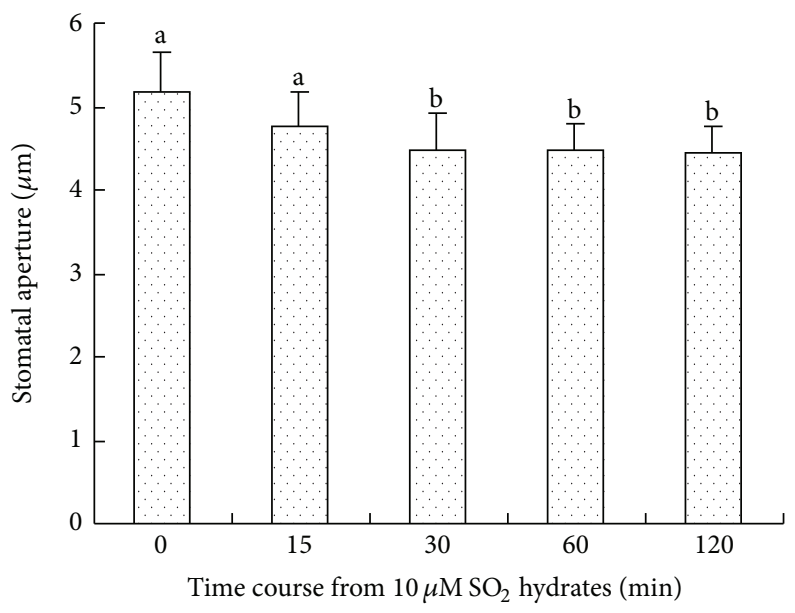

(c)

FIgURE 1: Promotion of stomatal closure by $\mathrm{SO}_{2}$ and its reversibility upon $\mathrm{SO}_{2}$ removal. Stomata of Arabidopsis leaf epidermis were allowed to open in light $[(\mathrm{a})$ and $(\mathrm{c})]$ or to close in the dark (b) for $2 \mathrm{~h}$ and then were incubated for $2 \mathrm{~h}$ in $\mathrm{SO}_{2}$ hydrates. b, A significant difference at $P<0.05$ from control. c, A significant difference at $P<0.05$ between $\mathrm{SO}_{2}$ treatment and its recovery group.

(Figure 1) but also evoked increased $\mathrm{H}_{2} \mathrm{O}_{2}$ level (1.2- to 1.7-fold) in Arabidopsis guard cells (Figure 2). When $\mathrm{H}_{2} \mathrm{O}_{2}$ elevation was blocked by exogenous $\mathrm{H}_{2} \mathrm{O}_{2}$ scavengers CAT or AsA, $\mathrm{SO}_{2}$-induced stomatal closure was efficiently reversed (Figure 2). These results indicate that $\mathrm{H}_{2} \mathrm{O}_{2}$ production in $\mathrm{SO}_{2}$-stimulated guard cells mediates stomatal movement upon $\mathrm{SO}_{2}$ stress.

3.2. $\mathrm{SO}_{2}$-Evoked $\mathrm{H}_{2} \mathrm{O}_{2}$ Elevation Triggered Cell Death. To investigate the role of $\mathrm{H}_{2} \mathrm{O}_{2}$ in irreversible stomatal closure in response to $\mathrm{SO}_{2}$, we detect the viability of Arabidopsis guard cells by double staining with fluorescein diacetate (FDA) and propidium iodide (PI). The results showed that $\mathrm{SO}_{2}$ induced guard cell death in a concentration-dependent manner (Figure 3). Cell death reached $24 \%$ in $6 \mathrm{mM} \mathrm{SO}_{2}$ hydrates treatment group, but no obvious cell death could be observed in 10 to $200 \mu \mathrm{M} \mathrm{SO}_{2}$ hydrates treatment groups. The $\mathrm{H}_{2} \mathrm{O}_{2}$ level of guard cells exposed to 2 to $6 \mathrm{mM} \mathrm{SO}_{2}$ hydrates showed a statistically significant increase (1.90- to 2.30 -fold), which is higher than those exposed to 10 to $500 \mu \mathrm{M} \mathrm{SO}_{2}$ hydrates. Moreover, exposure to $\mathrm{SO}_{2}$ hydrates simultaneously with $200 \mathrm{U} \cdot \mathrm{mL}^{-1}$ CAT or $0.1 \mathrm{mM}$ AsA, $\mathrm{SO}_{2}$ induced cell death was efficiently blocked, associated with a significant decrease in $\mathrm{H}_{2} \mathrm{O}_{2}$ level of guard cells (Figure 3). These results clearly demonstrate that an elevated $\mathrm{H}_{2} \mathrm{O}_{2}$ level can trigger guard cell death leading to stomatal dysfunction and irreversible stomatal closure in $\mathrm{SO}_{2}$-treated Arabidopsis leaves.

To further confirm the role of $\mathrm{H}_{2} \mathrm{O}_{2}$ in $\mathrm{SO}_{2}$ toxicity, we investigate the protective effects of CAT on cell viability 

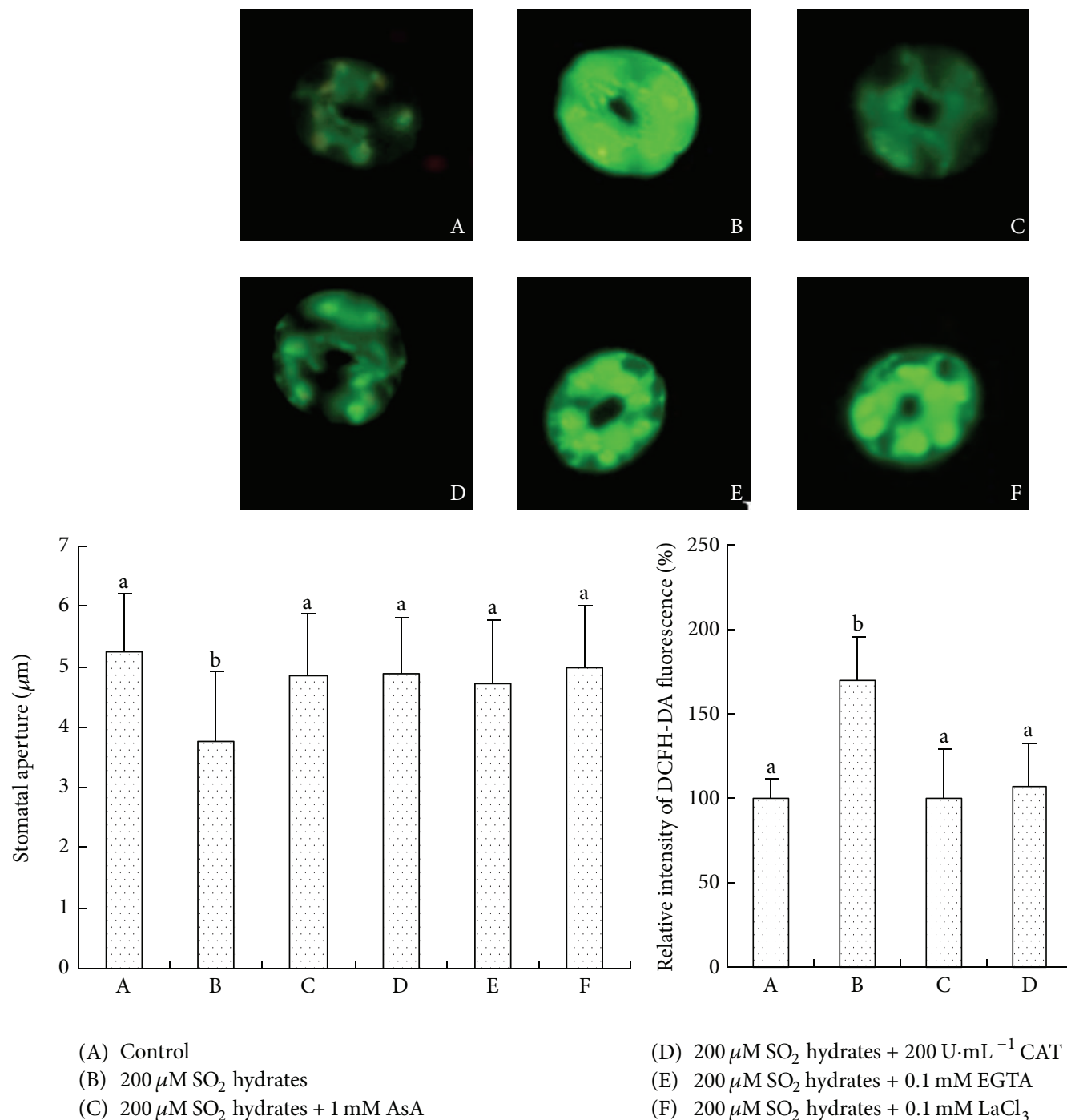
(A) Control
(B) $200 \mu \mathrm{M} \mathrm{SO}_{2}$ hydrates
(C) $200 \mu \mathrm{M} \mathrm{SO}_{2}$ hydrates $+1 \mathrm{mM} \mathrm{AsA}$
(F) $200 \mu \mathrm{M} \mathrm{SO}_{2}$ hydrates $+0.1 \mathrm{mM} \mathrm{LaCl}_{3}$

Figure 2: Effects of antioxidants and calcium antagonists on $\mathrm{SO}_{2}$-induced stomatal closure and $\mathrm{H}_{2} \mathrm{O}_{2}$ elevation in Arabidopsis guard cells. Different superscript letters indicate significant differences $(P<0.01)$. The same letters indicate no significant difference. The green fluorescence (DCFH-DA) of guard cells indicates $\mathrm{H}_{2} \mathrm{O}_{2}$ content.

in $\mathrm{SO}_{2}$-treated samples. The results showed that application of $1000 \mathrm{U} \cdot \mathrm{mL}^{-1}$ CAT could completely block the cell death evoked by $2 \mathrm{mM}$ and lower concentrations of $\mathrm{SO}_{2}$ hydrates, but the cytotoxicity evoked by $6 \mathrm{mM} \mathrm{SO}_{2}$ hydrates was only partly blocked (Figure 4 ). These results clearly demonstrate that $\mathrm{H}_{2} \mathrm{O}_{2}$ production, which may work together with other molecules, is enough to trigger $\mathrm{SO}_{2}$ toxicity.

\section{3. $\mathrm{H}_{2} \mathrm{O}_{2}$ Action Is Dependent on Its Concentrations and} Spatial Generation Patterns. As shown above, $\mathrm{SO}_{2}$ can cause stomatal closing and decline in cell viability, which is dependent on $\mathrm{SO}_{2}$ concentrations and $\mathrm{H}_{2} \mathrm{O}_{2}$ level. However, there was no clear dividing line between a safe level and a toxic level. In order to understand what constitutes a safe level, an inhibitor of NADPH oxidase was used to detect its inhibitory effects. The results show that application of $20 \mu \mathrm{M}$ NADPH oxidase inhibitor DPI for $2 \mathrm{~h}$ markedly blocked cell death evoked by $2 \mathrm{mM} \mathrm{SO}_{2}$ hydrates. But $20 \mu \mathrm{M}$ DPI did not inhibit stomatal closing evoked by $10 \mu \mathrm{M} \mathrm{SO}_{2}$ hydrates (Figure 4). These findings indicate that $\mathrm{SO}_{2}$-triggered stomatal closing can be driven by NADPH oxidase-dependent and -independent $\mathrm{H}_{2} \mathrm{O}_{2}$ generation, but NADPH oxidasedependent $\mathrm{H}_{2} \mathrm{O}_{2}$ generation is involved in $\mathrm{SO}_{2}$-caused cytotoxicity.

3.4. $\mathrm{H}_{2} \mathrm{O}_{2}$ Acts Upstream of $\mathrm{Ca}^{2+}$ Signaling in Response to $\mathrm{SO}_{2}$ Stress. $\mathrm{SO}_{2}$ exposure enhanced the fluorescence intensity of Fluo-3 AM ( $\mathrm{Ca}^{2+}$ indicator) in Arabidopsis guard cells. The relative fluorescence intensity of Fluo-3 AM, resulting from more than 600 guard cells per treatment group in three independent experiments, increased obviously in guard cells exposed to $10 \mu \mathrm{M}$ to $6 \mathrm{mM} \mathrm{SO}_{2}$ hydrates for $2 \mathrm{~h}$ but decreased markedly when isolated strips were treated simultaneously with $\mathrm{SO}_{2}$ hydrates and $0.1 \mathrm{mM}$ calcium channel blocker $\mathrm{LaCl}_{3}$ 

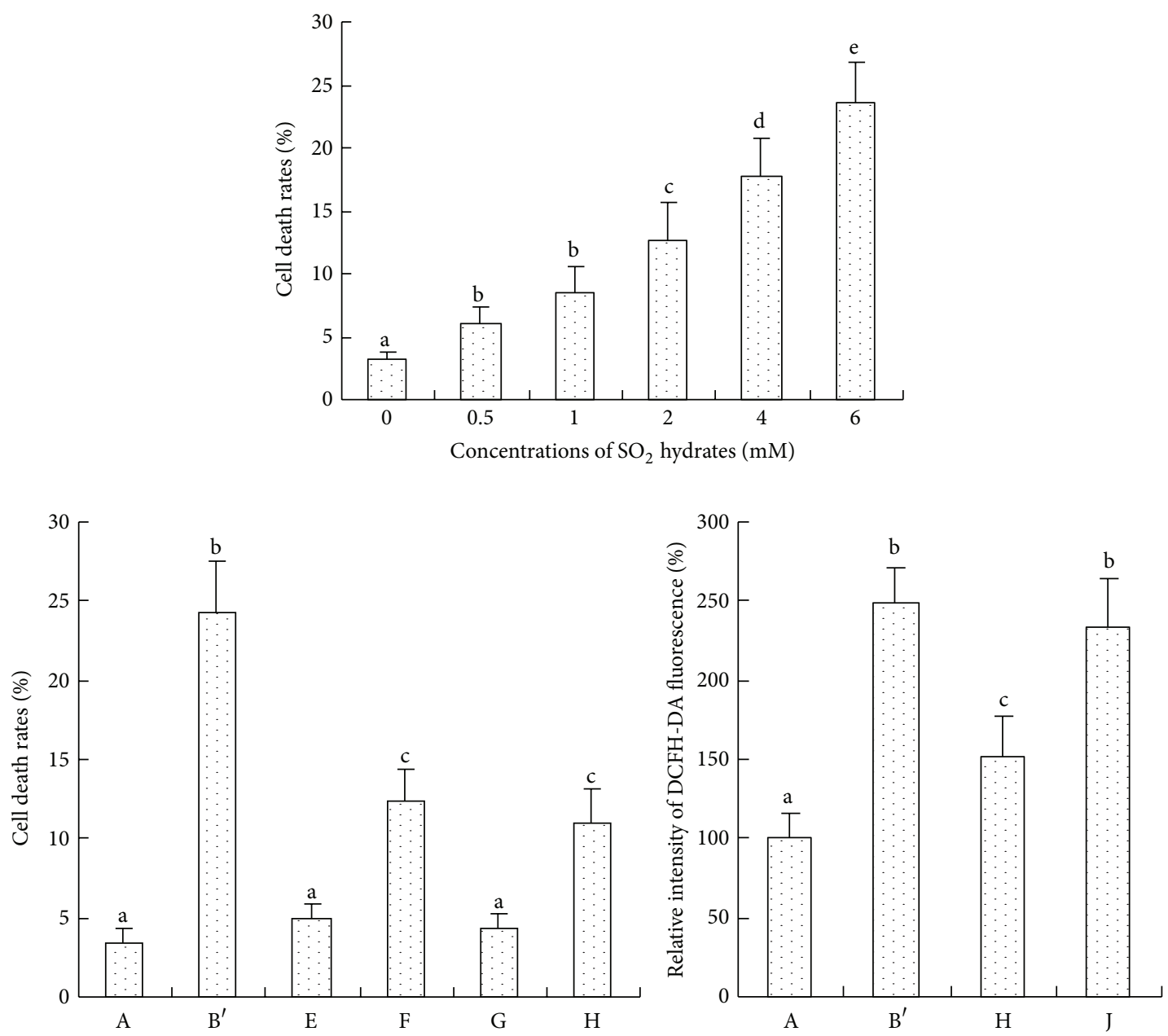
(A) Control
(B') $6 \mathrm{mM} \mathrm{SO}_{2}$ hydrates
(E) $0.1 \mathrm{mM}$ AsA
(F) $6 \mathrm{mM} \mathrm{SO}_{2}$ hydrates $+0.1 \mathrm{mM} \mathrm{AsA}$

(G) $200 \mathrm{U} \cdot \mathrm{mL}^{-1} \mathrm{CAT}$

(H) $6 \mathrm{mM} \mathrm{SO}_{2}$ hydrates $+200 \mathrm{U} \cdot \mathrm{mL}^{-1} \mathrm{CAT}$

(J) $6 \mathrm{mM} \mathrm{SO}_{2}$ hydrates $+0.1 \mathrm{mM} \mathrm{LaCl}_{3}$

FIgURE 3: Sulfur dioxide caused viability decline associated with $\mathrm{H}_{2} \mathrm{O}_{2}$ elevation in Arabidopsis guard cells. Different superscript letters indicate significant differences $(P<0.01)$. The same letters indicate no significant difference.

(Figure 5). These results indicate that $\mathrm{SO}_{2}$ exposure evokes an elevation of $\left[\mathrm{Ca}^{2+}\right]_{\text {cyt }}$ level, and $\mathrm{Ca}^{2+}$ influx through $\mathrm{Ca}^{2+}$ channels in the plasma membrane results in $\left[\mathrm{Ca}^{2+}\right]_{\mathrm{cyt}}$ elevation.

As shown in Figures 2 and 5, the addition of $\mathrm{LaCl}_{3}$ and calcium chelator EGTA to $\mathrm{SO}_{2}$ hydrates blocked $\left[\mathrm{Ca}^{2+}\right]_{\mathrm{cyt}}$ elevation, stomatal closure, and cell death evoked by $\mathrm{SO}_{2}$. Stomatal closure and cell death occurred with increased $\left[\mathrm{Ca}^{2+}\right]_{\text {cyt }}$ in $\mathrm{SO}_{2}$-treated samples, but both of them were significantly suppressed by $0.1 \mathrm{mM} \mathrm{LaCl} \mathrm{L}_{3}$ or EGTA. These results indicate that elevated $\left[\mathrm{Ca}^{2+}\right]_{\text {cyt }}$ level is an important stimulus driving stomatal movement and cytotoxicity.

To understand the pathways to plant responses, we study the signaling pathways in Arabidopsis guard cells. As shown in Figures 2, 3, and 5, both antioxidants AsA and CAT and $\mathrm{Ca}^{2+}$ antagonists $\mathrm{LaCl}_{3}$ and EGTA can suppress $\mathrm{SO}_{2}$-induced stomatal closure and cell death, but application of $\mathrm{H}_{2} \mathrm{O}_{2}$ scavenger CAT $\left(200 \mathrm{U} \cdot \mathrm{mL}^{-1}\right)$ decreased $\left[\mathrm{Ca}^{2+}\right]_{\text {cyt }}$ elevation evoked by $\mathrm{SO}_{2}$, whereas application of $\mathrm{Ca}^{2+}$ channel inhibitor $\mathrm{LaCl}_{3}(0.1 \mathrm{mM})$ did not affect $\mathrm{H}_{2} \mathrm{O}_{2}$ elevation evoked by $\mathrm{SO}_{2}$. These results confirm the involvement of $\mathrm{Ca}^{2+}$ downstream of $\mathrm{H}_{2} \mathrm{O}_{2}$ production, indicating that $\mathrm{H}_{2} \mathrm{O}_{2}$ triggers stomatal movement and cell death via $\mathrm{Ca}^{2+}$ signaling in plant response to $\mathrm{SO}_{2}$ stress.

\section{Discussion}

Plant could adapt to environmental challenges through various means. Our recent findings showed that $\mathrm{SO}_{2}$ fumigation caused an increased ROS production accompanied with differential gene expression and stomatal closure in Arabidopsis plants $[12,20]$. The results of the present study 

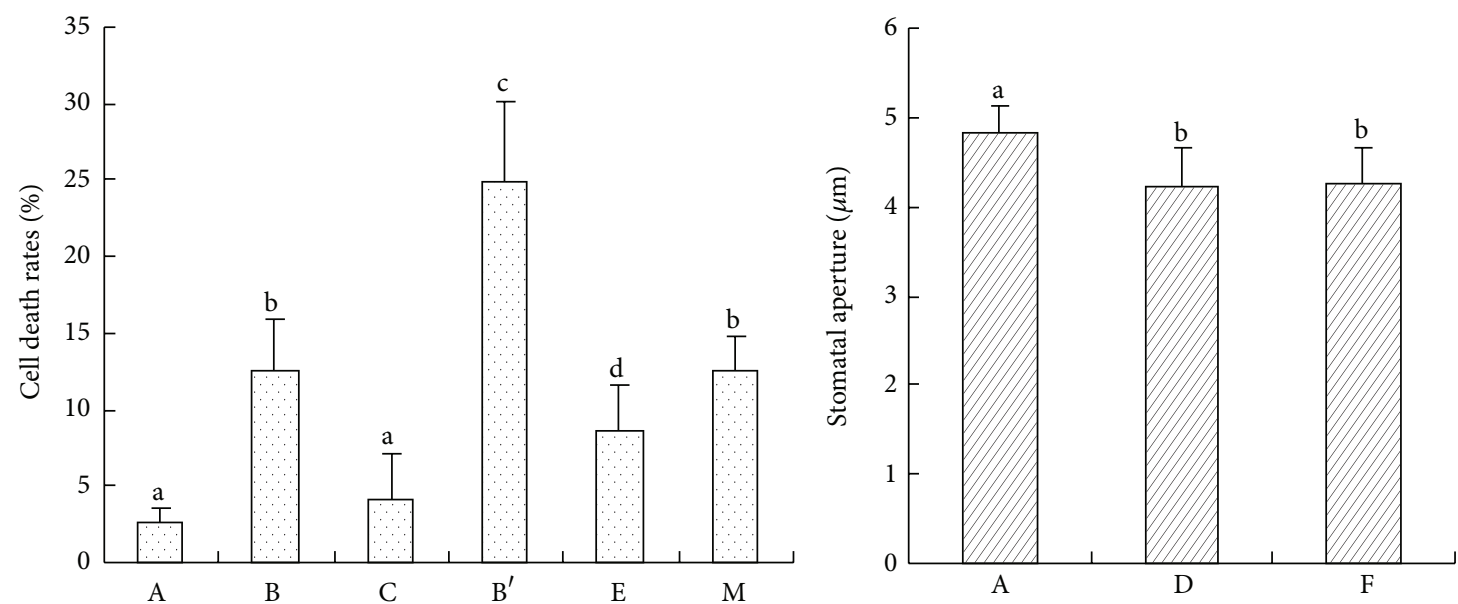
(A) Control
(B) $2 \mathrm{mM} \mathrm{SO}_{2}$ hydrates
(C) $2 \mathrm{mM} \mathrm{SO}_{2}$ hydrates $+1000 \mathrm{U} \cdot \mathrm{mL}^{-1} \mathrm{CAT}$
(B') $6 \mathrm{mM} \mathrm{SO}_{2}$ hydrates

(E) $6 \mathrm{mM} \mathrm{SO}_{2}$ hydrates $+1000 \mathrm{U} \cdot \mathrm{mL}^{-1} \mathrm{CAT}$

(M) $6 \mathrm{mM} \mathrm{SO}_{2}$ hydrates $+20 \mu \mathrm{M} \mathrm{DPI}$

(D) $10 \mu \mathrm{M} \mathrm{SO}_{2}$ hydrates

(F) $10 \mu \mathrm{M} \mathrm{SO}_{2}$ hydrates $+20 \mu \mathrm{M} \mathrm{DPI}$

FIGURE 4: Hydrogen peroxide scavenger and NADPH oxidase inhibitor DPI blocked $\mathrm{SO}_{2}$-induced cell death, but DPI cannot block $\mathrm{SO}_{2}$ induced stomatal closure. Different superscript letters indicate significant difference at $P<0.01$. The same letters indicate no significant difference.

show the evidences that $\mathrm{H}_{2} \mathrm{O}_{2}$ acts as an important signaling molecule triggering stomatal movement and cell death in plant response to $\mathrm{SO}_{2}$. $\mathrm{SO}_{2}$-caused cell viability decline could interfere with the normal function of stomata to further affect plant physiology under environmental stress. However, the occurrence of $\mathrm{SO}_{2}$-caused guard cell death was associated with decreased stomatal aperture, suggesting the existence of a complex signaling network in plant responses to environmental stress.

Environmental challenges including biotic and abiotic stresses could induce ROS production in plant cells [25]. It has been documented that ROS play an important role in signal transduction of stomatal movement regulation and gene expression activation in plant response to environmental stresses [26-29]. ROS, which can be used as rapid long-distance autopropagating signals that are transferred throughout the plant in response to different environmental conditions, are widely considered to be an important player in guard cell signaling $[26,30]$. The data presented above indicate a requirement for $\mathrm{H}_{2} \mathrm{O}_{2}$ production in plant response to $\mathrm{SO}_{2}$ stress. First, $\mathrm{SO}_{2}$ induces stomatal closure and cell death associated with an increased intracellular $\mathrm{H}_{2} \mathrm{O}_{2}$ level (Figures 2 and 3). Second, two types of $\mathrm{H}_{2} \mathrm{O}_{2}$ scavengers CAT and AsA could block $\mathrm{SO}_{2}$-evoked stomatal closure and cell death; in particular, the effects of $\mathrm{SO}_{2}$ at low concentrations could be completely reversed by CAT (Figures 2 and 4). Third, $\mathrm{H}_{2} \mathrm{O}_{2}$ scavenger blocks the $\mathrm{SO}_{2}$-induced increase in intracellular $\mathrm{Ca}^{2+}$ required for stomatal closure and toxicity (Figure 5). Our study, validating the strong positive correlation between intracellular $\mathrm{H}_{2} \mathrm{O}_{2}$ level and stomatal closure/cell death, demonstrates a key role of $\mathrm{H}_{2} \mathrm{O}_{2}$ as trigger of stomatal closure and/or guard cell death in response to $\mathrm{SO}_{2}$.
Sulfur dioxide inhibited light-promoted stomatal opening and promoted stomatal closure leading to the smaller size of Arabidopsis stomata. High concentrations of $\mathrm{SO}_{2}$ also caused viability loss of Arabidopsis guard cells. The time course experiments show that $\mathrm{H}_{2} \mathrm{O}_{2}$ level of guard cells increased gradually during $\mathrm{SO}_{2}$ exposure (date not shown); therefore, an increased $\mathrm{H}_{2} \mathrm{O}_{2}$ level in $\mathrm{SO}_{2}$-stimulated Arabidopsis cells might trigger stomatal closure firstly and then cell viability loss through ROS-mediated cell death pathway as shown in $V$. faba cells [24] or through the gradual accumulation of free radical damage to biomolecules during $\mathrm{SO}_{2}$ exposure.

There are two primary sources of $\mathrm{H}_{2} \mathrm{O}_{2}$ in guard cells: chloroplasts and plasma membrane-associated NADPH oxidase $[22,31,32]$. The results of the time course experiments with single cell assays using the fluorescent probe DCFH-DA showed that $\mathrm{H}_{2} \mathrm{O}_{2}$ generation was dependent on $\mathrm{SO}_{2}$ concentration and that the increase in fluorescence intensity of chloroplasts occurred significantly earlier than within the other regions of guard cells (date not shown), demonstrating an enhanced $\mathrm{H}_{2} \mathrm{O}_{2}$ production in chloroplasts of guard cells. NADPH oxidase in plasma membrane contributes to $\mathrm{O}^{2}$. generation and ROS elevation in plant responses to abiotic stresses [33]. Application of DPI, which is widely accepted as a relatively specific direct inhibitor of NADPH oxidase, markedly blocked $\mathrm{SO}_{2}$-induced cell death but cannot suppress stomatal closure evoked by low concentrations of $\mathrm{SO}_{2}$. These findings indicate that $\mathrm{H}_{2} \mathrm{O}_{2}$ mediated stomatal closure in Arabidopsis leaves exposed to low concentrations of $\mathrm{SO}_{2}$ is not dependent on the activity of plasma membrane NADPH oxidase, but cell death evoked by high concentrations of $\mathrm{SO}_{2}$ is NADPH oxidase-dependent. 

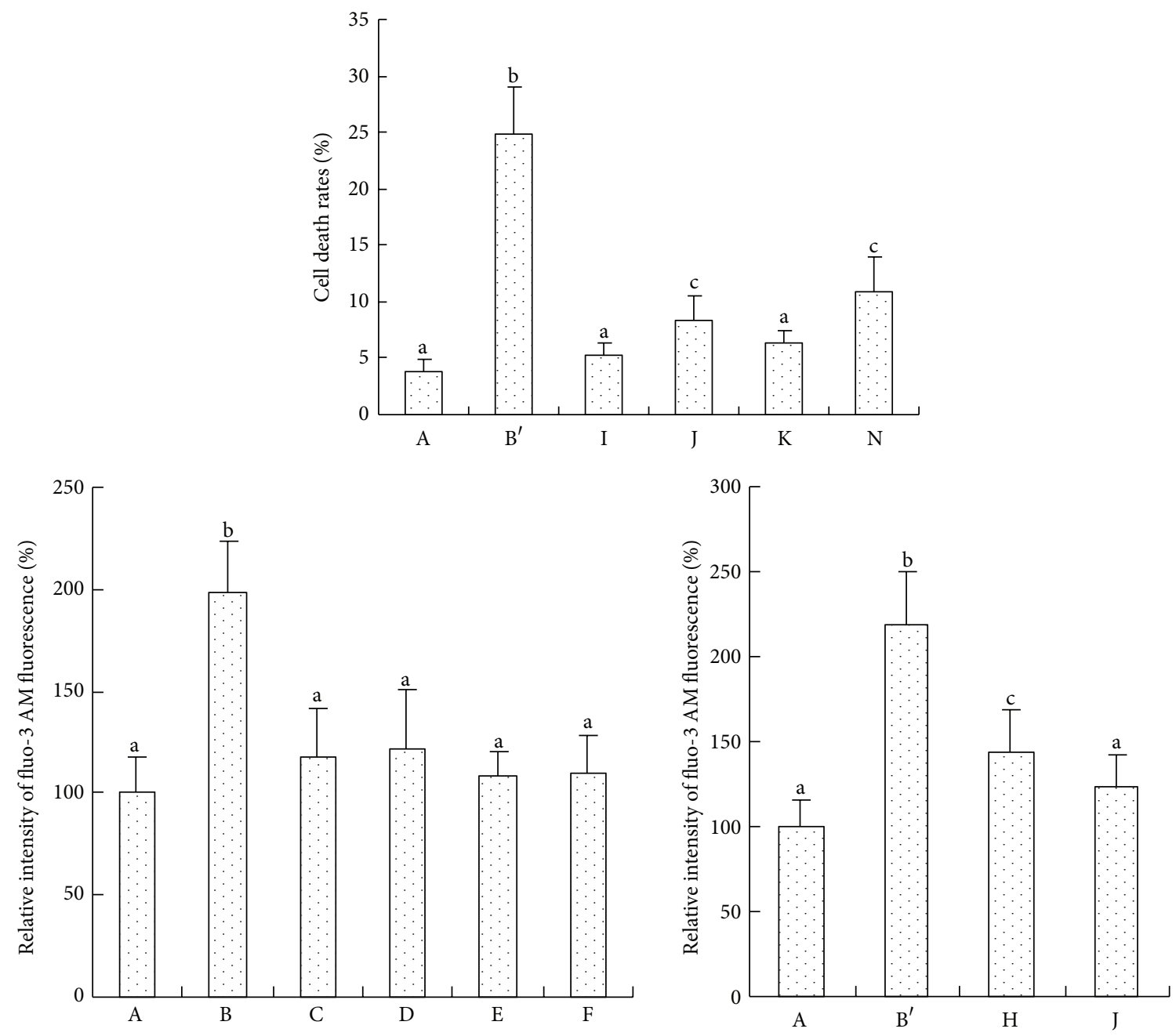
(A) Control
(B) $200 \mu \mathrm{M} \mathrm{SO}_{2}$ hydrates
(C) $200 \mu \mathrm{M} \mathrm{SO}_{2}$ hydrates $+1 \mathrm{mM} \mathrm{AsA}$
(D) $200 \mu \mathrm{M} \mathrm{SO}_{2}$ hydrates $+200 \mathrm{U} \cdot \mathrm{mL}^{-1} \mathrm{CAT}$
(E) $200 \mu \mathrm{M} \mathrm{SO}_{2}$ hydrates $+0.1 \mathrm{mM}$ EGTA
(J) $6 \mathrm{mM} \mathrm{SO}_{2}$ hydrates $+0.1 \mathrm{mM} \mathrm{LaCl}_{3}$
(F) $200 \mu \mathrm{M} \mathrm{SO}_{2}$ hydrates $+0.1 \mathrm{mM} \mathrm{LaCl}_{3}$
(K) $0.1 \mathrm{mM}$ EGTA
(B') $6 \mathrm{mM} \mathrm{SO}_{2}$ hydrates
(N) $6 \mathrm{mM} \mathrm{SO}_{2}$ hydrates $+0.1 \mathrm{mM} \mathrm{EGTA}$
(I) $0.1 \mathrm{mM} \mathrm{LaCl}_{3}$
(H) $6 \mathrm{mM} \mathrm{SO}_{2}$ hydrates $+200 \mathrm{U} \cdot \mathrm{mL}^{-1} \mathrm{CAT}$

FIGURE 5: Effects of antioxidants and $\mathrm{Ca}^{2+}$ antagonists on $\mathrm{SO}_{2}$-induced $\mathrm{Ca}^{2+}$ elevation and cell death in Arabidopsis guard cells. Different superscript letters indicate significant differences $(P<0.01)$. The same letters indicate no significant difference.

$\mathrm{SO}_{2}$ exposure caused stomatal closure and guard cell death associated with $\left[\mathrm{Ca}^{2+}\right]_{\mathrm{cyt}}$ elevation, whereas application of either $\mathrm{Ca}^{2+}$ chelator EGTA or $\mathrm{Ca}^{2+}$ channel inhibitor $\mathrm{LaCl}_{3}$ blocking $\mathrm{SO}_{2}$-evoked $\left[\mathrm{Ca}^{2+}\right]_{\text {cyt }}$ elevation, stomatal closure and cell death evoked by $\mathrm{SO}_{2}$ were effectively blocked. These results demonstrate that a channel-mediated $\mathrm{Ca}^{2+}$ influx across the plasma membrane contributes to the elevation of $\left[\mathrm{Ca}^{2+}\right]_{\mathrm{cyt}}$ and subsequent stomatal closure and cell death in $\mathrm{SO}_{2}$-stimulated guard cells. However, it is not clear how $\mathrm{Ca}^{2+}$ signaling recognizes the different situations of cells to mediate appropriate processes such as stomatal closure and cell death.

It has been found that $\mathrm{H}_{2} \mathrm{O}_{2}$ could activate plasma membrane $\mathrm{Ca}^{2+}$ channels leading to $\left[\mathrm{Ca}^{2+}\right]_{\text {cyt }}$ increase in plant cells [34-36]. Therefore, $\mathrm{H}_{2} \mathrm{O}_{2}$ activation of plasma membrane $\mathrm{Ca}^{2+}$ channels may be a central step in $\mathrm{SO}_{2}$ induced stomatal closure and/or cell death. The results of our present study also showed that application of antioxidant CAT and AsA significantly decreased $\mathrm{SO}_{2}$-evoked $\left[\mathrm{Ca}^{2+}\right]_{\text {cyt }}$ elevation, but application of $\mathrm{Ca}^{2+}$ channel blocker $\mathrm{LaCl}_{3}$ did not affect $\mathrm{SO}_{2}$-evoked $\mathrm{H}_{2} \mathrm{O}_{2}$ increase, indicating that $\mathrm{H}_{2} \mathrm{O}_{2}$ acts upstream of $\mathrm{Ca}^{2+}$ signaling in $\mathrm{SO}_{2}$ induced stomatal closure and/or cell death. These observations were consistent with other previous reports that a $\left[\mathrm{Ca}^{2+}\right]_{\text {cyt }}$ increase was linked to $\mathrm{H}_{2} \mathrm{O}_{2}$ production and was involved in ROS-mediated stomatal closure/cell death [37-39]. Therefore, $\mathrm{H}_{2} \mathrm{O}_{2}$ elevation and subsequent activation of $\mathrm{Ca}^{2+}$ channels are events occurring in $\mathrm{SO}_{2}$-induced stomatal closure/cell death. $\mathrm{Ca}^{2+}$ influx from extracellular 
region results in $\left[\mathrm{Ca}^{2+}\right]_{\text {cyt }}$ increase, and then $\left[\mathrm{Ca}^{2+}\right]_{\text {cyt }}$ elevation mediates subsequent stomatal closure/cell death. These results suggested that $\mathrm{H}_{2} \mathrm{O}_{2}$ mediates $\mathrm{SO}_{2}$-induced stomatal movement/cytotoxicity by targeting $\mathrm{Ca}^{2+}$ channels in the plasma membrane.

Briefly, environmental $\mathrm{SO}_{2}$ has a remarkable effect on the size of the stomatal aperture. Exposure to $\mathrm{SO}_{2}$ induced the overproduction of $\mathrm{H}_{2} \mathrm{O}_{2}$ in guard cells, as shown in other plant cells exposed to environmental challenges [40, 41]. Elevated $\mathrm{H}_{2} \mathrm{O}_{2}$ acts in conjunction with other factors to activate stomatal movement and cell death under $\mathrm{SO}_{2}$ stress. Guard cells are a well-developed model system for characterizing early signal transduction mechanisms in plants. In this study, the dual role of $\mathrm{H}_{2} \mathrm{O}_{2}$ in plant cells in response to air pollutant was clearly displayed in Arabidopsis guard cells, which additionally broaden the role of stomatal guard cells in cytotoxicity study. Our results suggest that guard cells are a valuable model system for the study of cytotoxicity in plant cells.

\section{Conclusion}

Sulfur dioxide exposure caused an elevated $\mathrm{H}_{2} \mathrm{O}_{2}$ level in Arabidopsis guard cells. $\mathrm{H}_{2} \mathrm{O}_{2}$ elevation triggered by $\mathrm{SO}_{2}$ mediated both stomatal closure and cell death via $\mathrm{Ca}^{2+}$ signaling. Intracellular $\mathrm{Ca}^{2+}$ increase is necessary for stomatal closure and cell death in Arabidopsis guard cells in response to $\mathrm{SO}_{2} \cdot \mathrm{H}_{2} \mathrm{O}_{2}$ production by NADPH oxidase plays a critical role in $\mathrm{SO}_{2}$ toxicity; however NADPH oxidase activation is sufficient but not necessary for $\mathrm{SO}_{2}$-triggered stomatal closure. Both stomatal closing and stomatal opening inhibition evoked by $\mathrm{SO}_{2}$ lead to a decline in stomatal aperture, protecting the leaf against further entry of the pollutant but also curtailing photosynthesis. Cell death evoked by high concentrations of $\mathrm{SO}_{2}$ indicated the cytotoxicity of $\mathrm{SO}_{2}$, but might provide appropriate protection by reducing ROS production in Arabidopsis plants.

\section{Conflict of Interests}

The authors declare that there is no conflict of interests regarding the publication of this paper.

\section{Acknowledgments}

This study was supported by the National Natural Science Foundation of China (Grant nos. 30870454, 30470318, and 31371868), Research Fund for the Doctoral Program of Higher Education of China (Grant no. 20070108007), and Shanxi Scholarship Council of China (Grant no. 2009022).

\section{References}

[1] N. M. Darrall, "The effect of air pollutants on physiological processes in plants," Plant, Cell \& Environment, vol. 12, no. 1, pp. 1-30, 1989.

[2] T. Hogetsu and M. Shishikura, "Effects of sulfur dioxide and ozone on intact leaves and isolated mesophyll cells of groundnut plants (Arachis hypogaea L.)," Journal of Plant Research, vol. 107, no. 3, pp. 229-235, 1994.

[3] M. Noji, M. Saito, M. Nakamura, M. Aono, H. Saji, and K. Saito, "Cysteine synthase overexpression in tobacco confers tolerance to sulfur-containing environmental pollutants," Plant Physiology, vol. 126, no. 3, pp. 973-980, 2001.

[4] R. Rakwal, G. K. Agrawal, A. Kubo et al., "Defense/stress responses elicited in rice seedlings exposed to the gaseous air pollutant sulfur dioxide," Environmental and Experimental Botany, vol. 49, no. 3, pp. 223-235, 2003.

[5] H. Rennenberg and C. Herschbach, "Responses of plants to atmospheric sulphur," in Plant Response to Air Pollution, M. Yunus and M. Iabal, Eds., pp. 285-294, John Wiley \& Sons, Chichester, UK, 1996.

[6] H. Pfanz and U. Heber, "Buffer capacities of leaves, leaf cells, and leaf cell organelles in relation to fluxes of potentially acidic gases," Plant Physiology, vol. 81, pp. 597-602, 1986.

[7] K. Asada, "Formation and scavenging of superoxides in chloroplasts, with relation to injury by sulfur dioxide," Research Report of the National Institute for Environmental Studies, vol. 11, pp. 165-179, 1980.

[8] N. R. Madamanchi and R. G. Alscher, "Metabolic bases for differences in sensitivity of two pea cultivars to sulfur dioxide," Plant Physiology, vol. 97, no. 1, pp. 88-93, 1991.

[9] K. Tanaka, N. Kondo, and K. Sugahara, "Accumulation of hydrogen peroxide in chloroplasts of $\mathrm{SO}_{2}$-fumigated spinach leaves," Plant and Cell Physiology, vol. 23, no. 6, pp. 999-1007, 1982.

[10] R. Hänsch and R. R. Mendel, "Sulfite oxidation in plant peroxisomes," Photosynthesis Research, vol. 86, no. 3, pp. 337343, 2005.

[11] E. Giraud, A. Ivanova, C. S. Gordon, J. Whelan, and M. J. Considine, "Sulphur dioxide evokes a large scale reprogramming of the grape berry transcriptome associated with oxidative signalling and biotic defence responses," Plant, Cell and Environment, vol. 35, no. 2, pp. 405-417, 2012.

[12] L. Li and H. Yi, "Differential expression of Arabidopsis defenserelated genes in response to sulfur dioxide," Chemosphere, vol. 87, no. 7, pp. 718-724, 2012.

[13] J. Dat, S. Vandenabeele, E. Vranová, M. van Montagu, D. Inzé, and F. van Breusegem, "Dual action of the active oxygen species during plant stress responses," Cellular and Molecular Life Sciences, vol. 57, no. 5, pp. 779-795, 2000.

[14] P. Sharma, A. B. Jha, R. S. Dubey, and M. Pessarakli, "Reactive Oxygen species, oxidative damage, and antioxidative defense mechanism in plants under stressful conditions," Journal of Botany, vol. 2012, Article ID 217037, 26 pages, 2012.

[15] S. Neill, R. Desikan, and J. Hancock, "Hydrogen peroxide signalling," Current Opinion in Plant Biology, vol. 5, no. 5, pp. 388-395, 2002.

[16] C. Laloi, K. Apel, and A. Danon, "Reactive oxygen signalling: the latest news," Current Opinion in Plant Biology, vol. 7, no. 3, pp. 323-328, 2004.

[17] H. B. Shao, L. Y. Chu, Z. H. Lu, and C. M. Kang, "Primary antioxidant free radical scavenging and redox signaling pathways in higher plant cells," International Journal of Biological Sciences, vol. 4, no. 1, pp. 8-14, 2008.

[18] R. Mittler, "Oxidative stress, antioxidants and stress tolerance," Trends in Plant Science, vol. 7, no. 9, pp. 405-410, 2002.

[19] S.-H. Hung, C.-W. Yu, and C. H. Lin, "Hydrogen peroxide functions as a stress signal in plants," Botanical Bulletin of Academia Sinica, vol. 46, no. 1, pp. 1-10, 2005. 
[20] L. Li, H. Yi, L. Wang, and X. Li, "Effects of sulfur dioxide on the morphological and physiological biochemical parameters in Arabidopsis thaliana plants," Journal of Agro-Environment Science, vol. 27, pp. 525-529, 2008.

[21] A. M. Hetherington, "Guard cell signaling," Cell, vol. 107, no. 6, pp. 711-714, 2001.

[22] X. Zhang, L. Zhang, F. C. Dong, J. F. Gao, D. W. Galbraith, and C.-P. Song, "Hydrogen peroxide is involved in abscisic acidinduced stomatal closure in Vicia faba," Plant Physiology, vol. 126, no. 4, pp. 1438-1448, 2001.

[23] J. I. Schroeder, G. J. Allen, V. Hugouvieux, J. M. Kwak, and D. Waner, "Guard cell signal transduction," Annual Review of Plant Biology, vol. 52, pp. 627-658, 2001.

[24] H. Yi, J. Yin, X. Liu, X. Jing, S. Fan, and H. Zhang, "Sulfur dioxide induced programmed cell death in Vicia guard cells," Ecotoxicology and Environmental Safety, vol. 78, pp. 281-286, 2012.

[25] K. Apel and H. Hirt, "Reactive oxygen species: metabolism, oxidative stress, and signal transduction," Annual Review of Plant Biology, vol. 55, pp. 373-399, 2004.

[26] R. Desikan, M.-K. Cheung, A. Clarke et al., "Hydrogen peroxide is a common signal for darkness- and ABA-induced stomatal closure in Pisum sativum," Functional Plant Biology, vol. 31, no. 9, pp. 913-920, 2004.

[27] N. Suzuki, S. Koussevitzky, R. Mittler, and G. Miller, "ROS and redox signalling in the response of plants to abiotic stress," Plant, Cell and Environment, vol. 35, no. 2, pp. 259-270, 2012.

[28] T. Fukao and J. Bailey-Serres, "Plant responses to hypoxia-is survival a balancing act?" Trends in Plant Science, vol. 9, no. 9, pp. 449-456, 2004.

[29] R. Mittler, S. Vanderauwera, M. Gollery, and F. van Breusegem, "Reactive oxygen gene network of plants," Trends in Plant Science, vol. 9, no. 10, pp. 490-498, 2004.

[30] Y. Song, Y. Miao, and C.-P. Song, "Behind the scenes: the roles of reactive oxygen species in guard cells," New Phytologist, vol. 201, no. 4, pp. 1121-1140, 2014.

[31] Z.-M. Pel, Y. Murata, G. Benning et al., "Calcium channels activated by hydrogen peroxide mediate abscisic acid signalling in guard cells," Nature, vol. 406, no. 6797, pp. 731-734, 2000.

[32] V. D. Petrov and F. van Breusegem, "Hydrogen peroxide-a central hub for information flow in plant cells," AoB Plants, vol. 12, no. 1, Article ID pls014, 2012.

[33] M. A. Torres and J. L. Dangl, "Functions of the respiratory burst oxidase in biotic interactions, abiotic stress and development," Current Opinion in Plant Biology, vol. 8, no. 4, pp. 397-403, 2005.

[34] R. Mahalingam and N. Fedoroff, "Stress response, cell death and signalling: the many faces of reactive oxygen species," Physiologia Plantarum, vol. 119, no. 1, pp. 56-68, 2003.

[35] I. C. Mori and J. I. Schroeder, "Reactive oxygen species activation of plant $\mathrm{Ca}^{2+}$ channels. A signaling mechanism in polar growth, hormone transduction, stress signaling, and hypothetically mechanotransduction," Plant Physiology, vol. 135, no. 2, pp. 702-708, 2004.

[36] D. B. Kiselevsky, Y. E. Kuznetsova, L. A. Vasilev et al., "Effect of $\mathrm{Ca}^{2+}$ on programmed death of guard and epidermal cells of pea leaves," Biochemistry, vol. 75, no. 5, pp. 614-622, 2010.

[37] R. Errakhi, A. Dauphin, P. Meimoun et al., "An early $\mathrm{Ca}^{2+}$ influx is a prerequisite to thaxtomin A-induced cell death in Arabidopsis thaliana cells," Journal of Experimental Botany, vol. 59, no. 15, pp. 4259-4270, 2008.
[38] S. Orrenius, B. Zhivotovsky, and P. Nicotera, "Regulation of cell death: the calcium-apoptosis link," Nature Reviews Molecular Cell Biology, vol. 4, no. 7, pp. 552-565, 2003.

[39] F. Van Breusegem and J. F. Dat, "Reactive oxygen species in plant cell death," Plant Physiology, vol. 141, no. 2, pp. 384-390, 2006.

[40] M. C. de Pinto, V. Locato, and L. de Gara, "Redox regulation in plant programmed cell death," Plant, Cell and Environment, vol. 35, no. 2, pp. 234-244, 2012.

[41] T. Pfannschmidt, K. Bräutigam, R. Wagner et al., "Potential regulation of gene expression in photosynthetic cells by redox and energy state: approaches towards better understanding," Annals of Botany, vol. 103, no. 4, pp. 599-607, 2009. 

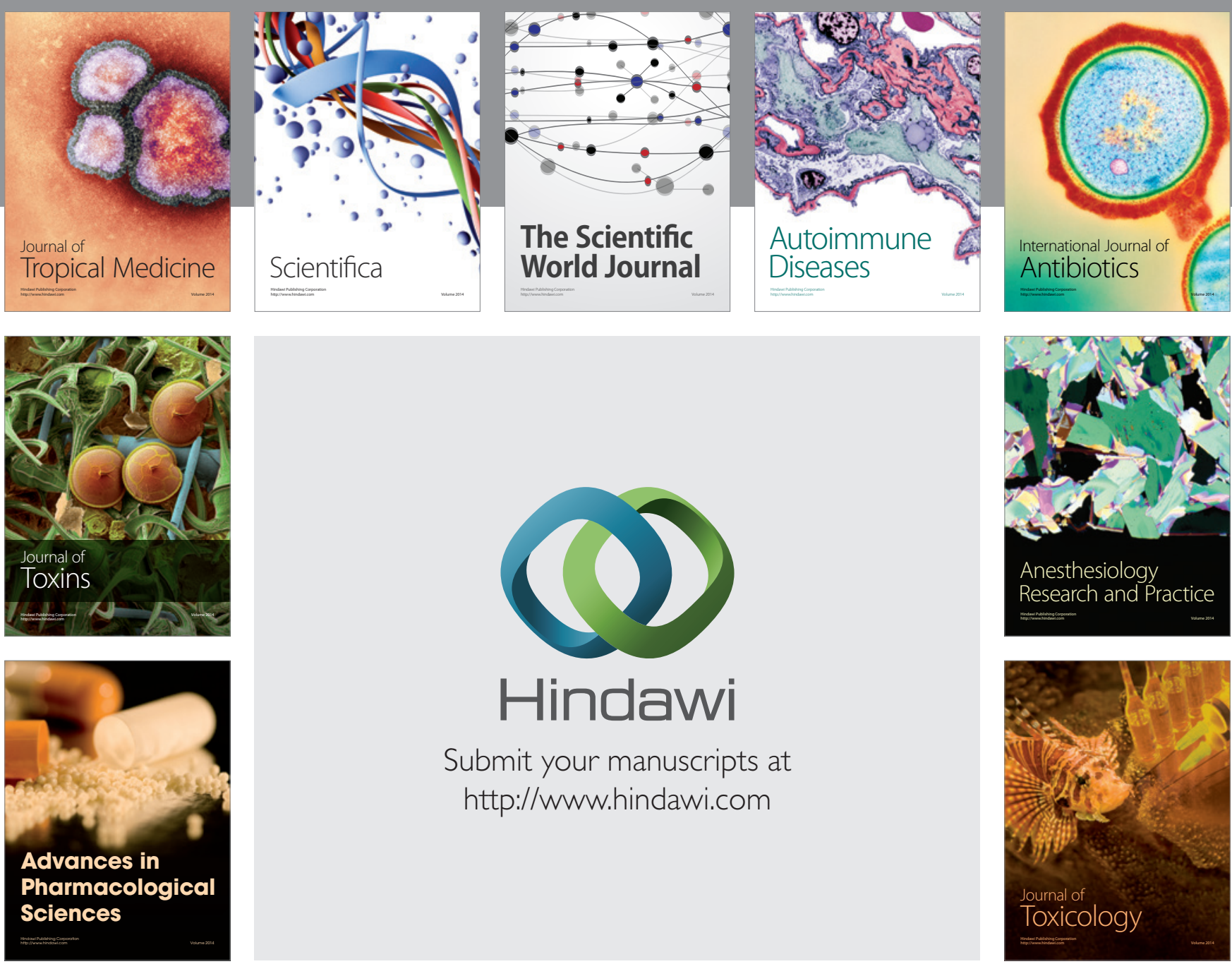

\section{Hindawi}

Submit your manuscripts at

http://www.hindawi.com
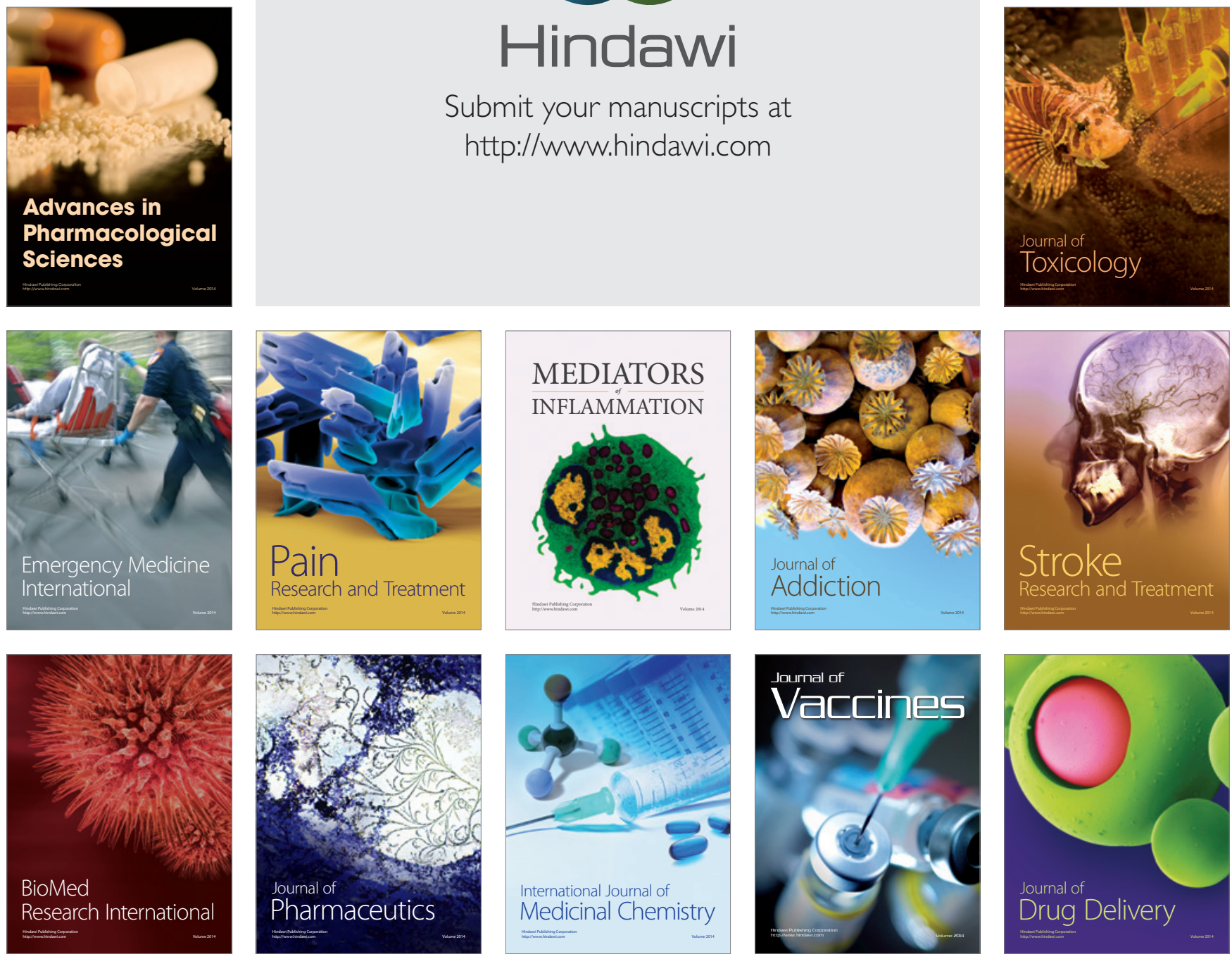